\title{
Evaluation of Toxicity and Antimicrobial Activity of an Ethanolic Extract from Leaves of Morus alba L. (Moraceae)
}

\author{
Alisson Macário de Oliveira, ${ }^{1,2}$ Matheus da Silva Mesquita, ${ }^{2}$ \\ Gabriela Cavalcante da Silva, ${ }^{2}$ Edeltrudes de Oliveira Lima, ${ }^{3}$ Paloma Lys de Medeiros, ${ }^{4}$ \\ Patrícia Maria Guedes Paiva, ${ }^{1}$ Ivone Antônia de Souza, ${ }^{2}$ and Thiago Henrique Napoleão ${ }^{1}$ \\ ${ }^{1}$ Departamento de Bioquímica, Centro de Ciências Biológicas, Universidade Federal de Pernambuco, 50670-420 Recife, PE, Brazil \\ ${ }^{2}$ Laboratório de Farmacologia e Cancerologia Experimental, Departamento de Antibióticos, Universidade Federal de Pernambuco, \\ 50670-420 Recife, PE, Brazil \\ ${ }^{3}$ Laboratório de Micologia, Departamento de Ciências Farmacêuticas, Centro de Ciências da Saúde, Universidade Federal da Paraíba, \\ 58059-900 João Pessoa, PB, Brazil \\ ${ }^{4}$ Departamento de Histologia e Embriologia, Centro de Ciências Biológicas, Universidade Federal de Pernambuco, \\ 50670-420 Recife, PE, Brazil
}

Correspondence should be addressed to Thiago Henrique Napoleão; thiagohn86@yahoo.com.br

Received 4 May 2015; Accepted 28 June 2015

Academic Editor: Ilaria Lampronti

Copyright (C) 2015 Alisson Macário de Oliveira et al. This is an open access article distributed under the Creative Commons Attribution License, which permits unrestricted use, distribution, and reproduction in any medium, provided the original work is properly cited.

\begin{abstract}
This work evaluated an ethanolic extract from Morus alba leaves for toxicity to Artemia salina, oral toxicity to mice, and antimicrobial activity. Phytochemical analysis revealed the presence of coumarins, flavonoids, tannins, and triterpenes in the extract, which did not show toxicity to A. salina nauplii. No mortality and behavioral alterations were detected for mice treated with the extract (300 and $2000 \mathrm{mg} / \mathrm{kg}$ b.w.) for 14 days. However, animals that received the highest dose showed reduced MCV and $\mathrm{MCHC}$ as well as increased serum alkaline phosphatase activity. In treatments with the extract at both $300 \mathrm{and} 2000 \mathrm{mg} / \mathrm{kg}$, there was a reduction in number of leukocytes, with decrease in percentage of lymphocytes and increase in proportion of segmented cells. Histopathological analysis of organs from mice treated with the extract at $2000 \mathrm{mg} / \mathrm{kg}$ revealed turgidity of contorted tubules in kidneys, presence of leukocyte infiltration around the liver centrilobular vein, and high dispersion of the spleen white pulp. The extract showed antimicrobial activity against Staphylococcus aureus, Pseudomonas aeruginosa, Candida albicans, Candida krusei, Candida tropicalis, and Aspergillus flavus. In conclusion, the extract contains antimicrobial agents and was not lethal for mice when ingested; however, its use requires caution because it promoted biochemical, hematological, and histopathological alterations.
\end{abstract}

\section{Introduction}

The use of plants as therapeutic tools is based on the popular culture and plant preparations are continually used by people, despite the large number of synthetic drugs developed. This has been mainly associated with the higher costs of allopathic medicines and a limited access of population to them, especially in developing countries where most of the people depend essentially on natural resources to address problems related to diseases of primary care [1]. The relevance of medicinal plants over the centuries has stimulated the search for scientifically proven information on their efficacy and safety for humans [2-4].

Morus genus (Moraceae) comprises a group of trees native from Asia, popularly known as mulberries, and with a great importance in folk medicine. In China, the leaves, roots, and branches of Morus species are used for treatment of fevers, hepatic protection, vision improvement, strengthening of joints, and reduction of blood pressure [5-7]. The leaves of different mulberries are consumed in Korea and Japan as a nutraceutical food and used for controlling blood glucose levels; this last property is attributed to the 
presence of the compound 1-deoxynojirimycin, a potent $\alpha$ glucosidase inhibitor [8]. Fukai et al. [9] isolated from Morus species a substance deemed chalcomoracin, which showed antimicrobial activity against methicillin-resistant Staphylococcus aureus. Dai et al. [10] isolated three compounds from Morus macroura bark, called guangsangon $\mathrm{H}$, guangsangon $\mathrm{I}$, and guangsangon J, which showed anti-inflammatory and antioxidant activities.

The pharmacological potential of the species Morus alba L. (white mulberry), for benefit of animals and humans, has been investigated. Flavonoids from root showed antiparasitic activity against Ichthyophthirius multifiliis, a parasite of gills and skin of freshwater fishes [11] and it was reported that a methanolic extract from the plant foliage might be used as a dietary supplement in order to alleviate Aeromonas hydrophila infection in catfish Clarias gariepinus [12]. DielsAlder adducts and prenylated flavanones isolated from the root bark of $M$. alba showed cytotoxic activity against human tumor cells [13]. In another study, a composition containing a blend of standardized extracts from Uncaria gambir leaves and $M$. alba root bark was reported to be useful as an alternative therapy for alleviating osteoarthritis and its associated symptoms [14]. Kim et al. [15] reported that extracts from $M$. alba leaves and fruits were able to reduce cognitive deficits in mice induced by the high-fat diet. Other reports mention antioxidant, antibacterial, antiviral, and neuroprotective activities from extracts and isolated compounds from fruits, leaves, stem, and root of M. alba [1620].

In face of the several reports on the medicinal properties of $M$. alba leaves, we investigated in this work the toxicity of an ethanolic extract from this tissue by using two models: Artemia salina lethality assay and assessment of in vivo oral toxicity to mice. In the last, biochemical, hematological, and histopathological analyses were also performed. In addition, it reports the phytochemical composition of the extract and the evaluation of its antimicrobial activity against pathogens with medical relevance.

\section{Materials and Methods}

2.1. Plant Material. Leaves of $M$. alba were collected in Petrolina city, Pernambuco, northeast Brazil. Taxonomic identification was performed and a voucher specimen (number 88372) is deposited in the herbarium of the Instituto Agronômico de Pernambuco, Recife, Brazil.

2.2. Extract Preparation. The ethanolic extract was chosen for this study because this solvent is able to dissolve both polar and nonpolar substances, including a variety of plantderived compounds. The leaves were washed with distilled water and dried at $28^{\circ} \mathrm{C}$ during $24 \mathrm{~h}$ and next in an oven at $45^{\circ} \mathrm{C}$ for 15 days; subsequently, the leaves were powdered. The leaf powder $(180 \mathrm{~g})$ was mixed with $70 \%$ (v/v) ethanol in distilled water and the mixture was allowed to rest for $48 \mathrm{~h}$, followed by mechanical agitation for $48 \mathrm{~h}$ using an orbital shaker. The extract was filtered and the solvent was removed using a rotary evaporator.
TABLE 1: Phytochemical screening of ethanolic extract from Morus alba leaves through thin layer chromatography.

\begin{tabular}{llc}
\hline Compound classes & Revealer & Result \\
\hline Alkaloids & Dragendorff's reagent & Negative \\
Anthraquinones & KOH & Negative \\
Coumarins & KOH & Positive \\
Steroids & Liebermann- & Negative \\
Flavonoids & Burchard & Positive \\
Tannins & Aluminum chloride & Positive for \\
& Iron (III) chloride & condensed tannins \\
Triterpenes & Liebermann- & Positive \\
\hline
\end{tabular}

2.3. Phytochemical Screening. The extract was evaluated for the presence of coumarins, flavonoids, tannins, steroids, alkaloids, anthraquinones, and triterpenes by thin layer chromatography (TLC). The assays were performed using the revealers listed in Table 1 and following the instructions described by Markhan [21], Wagner and Bladt [22], and Abreu [23].

2.4. Toxicity to Artemia salina. The assay was performed according to Meyer et al. [24] using A. salina cysts purchased from San Francisco Bay Brand, Inc. (USA). First, an artificial saline solution $(3.8 \%$, w/v) was prepared using sea salt (Marinex, Brazil) and distilled water. In each assay, 10 nauplii were added to extract solutions at different concentrations $(100-1,000 \mu \mathrm{g} / \mathrm{mL})$ prepared by diluting the extract in $10 \mathrm{~mL}$ of the artificial saline solution. In controls, the nauplii were incubated with the saline solution. Each concentration was tested in triplicate and three independent experiments were performed. The assays were maintained under artificial lighting for $24 \mathrm{~h}$ at $27 \pm 2^{\circ} \mathrm{C}$. After this period, the mortality rates were determined.

2.5. Oral Toxicity Assay. The experiments were performed using female Swiss mice (Mus musculus) weighing 38-50 g and reared in the vivarium of the Laboratório de Farmacologia e Cancerologia Experimental of the Universidade Federal de Pernambuco. The animals are maintained at temperature of $21 \pm 1^{\circ} \mathrm{C}, 12 \mathrm{~L}: 12 \mathrm{D}$ photoperiod and it is given ad libitum access to food (Purina) and water. The experimental procedures were approved by Animal Ethics Committee of the Universidade Federal de Pernambuco (process number 23076.061132/2014-33).

The dried extract was dissolved in $0.9 \%$ (w/v) $\mathrm{NaCl}$ [25] and acute toxicity (mortality and behavioral alterations) was evaluated by oral administration. The mice were separated in three groups ( $n=3$ for each group), according to the instructions of the Organization for Economic Cooperation and Development [26]: control group, which received saline solution (vehicle), and two test groups, which received the extract at $300 \mathrm{mg} / \mathrm{kg}$ and $2000 \mathrm{mg} / \mathrm{kg}$ b.w. The mice were observed during 14 days. 
2.6. Biochemical and Hematological Analyses. At the end of oral toxicity assays, the blood of animals was collected and the following biochemical parameters were evaluated: total protein, albumin, alanine aminotransferase (ALT), aspartate aminotransferase (AST), alkaline phosphate, gammaglutamyl transferase (GGT), urea, and creatinine, using specific kits (Labtest Diagnóstica, Lagoa Santa, Brazil) and a COBAS Mira Plus analyzer (Roche Diagnostics Systems, Basel, Switzerland). Hematologic analysis was performed using an automatic analyzer (Animal Blood Counter: ABC Vet, Montpellier, France) and optical microscopy; the parameters evaluated were as follows: erythrocytes, hemoglobin, hematocrit, mean corpuscular volume (MCV), mean corpuscular hemoglobin $(\mathrm{MCH})$, mean corpuscular hemoglobin concentration (MCHC), and total and differentiated analysis of leukocytes.

2.7. Histopathological Analysis. Histological analyses of liver, kidney, and spleen of animals from control and extract treatments were performed by optical microscopy. Fragments of the organs were fixed in buffered formalin $(10 \%, \mathrm{v} / \mathrm{v})$ and then dehydrated through a graded ethanol series (70$100 \%)$, diaphonized in xylol, and embedded in paraffin. Histological sections $(5 \mu \mathrm{m})$ were stained with hematoxylineosin and mounted using cover slips with Entellan resin (Merck, Germany) [27]. The materials were observed under a Motic BA200 microscopy coupled to a Moticam 10001.3 MP digital camera (Motic Incorporation Ltd., Causeway Bay, Hong Kong).

2.8. Antimicrobial Activity. The extract was evaluated for antibacterial activity against three strains of Staphylococcus aureus (ATCC-13150, M-177, and LM-197) and two strains of Pseudomonas aeruginosa (ATCC-9027 and P-03). Antifungal activity was evaluated against strains of Candida albicans (ATCC-76645 and LM-106), Candida tropicalis (ATCC13803 and LM-6), Candida krusei (LM-656 and LM-978), Aspergillus flavus (LM-118), and Aspergillus niger (LM-108). Bacterial suspensions were prepared in Nutrient Broth (Difco Laboratories, France) and fungal suspensions in RPMI 1640 medium (Acumedia, India). The suspensions were standardized for $10^{6}$ colony-forming units (CFU) per $\mathrm{mL}$ using a LeitzPhotometer 340-800 spectrophotometer.

The assays for determination of the minimal inhibitory concentrations (MIC) were performed in U-bottom 96-well microplates. In an assay, each plate well received $100 \mu \mathrm{L}$ of Nutrient Broth (for bacteria) or RPMI medium (for yeasts and filamentous fungi). Next, $100 \mu \mathrm{L}$ of the extract, dissolved in distilled water, was added in the wells of the first column of the plate and then a two-fold serial dilution was performed in each row to reach extract concentrations ranging from 32 to $1,024 \mu \mathrm{g} / \mathrm{mL}$. Finally, $10 \mu \mathrm{L}$ of microorganism suspension was added to each well. A 100\% growth control was done in absence of the extract and positive controls were performed using chloramphenicol $(100 \mu \mathrm{g} / \mathrm{mL})$ for bacteria as well as nystatin (100 IU) and fluconazole $(100 \mu \mathrm{g} / \mathrm{mL})$ for fungi. The plates were incubated for $24 \mathrm{~h}$ at $35^{\circ} \mathrm{C}$ in assays with bacteria and yeasts or for $7-10$ days at $28^{\circ} \mathrm{C}$ in assays with filamentous fungi. After $24 \mathrm{~h}$, bacterial growth was revealed by addition of $20 \mu \mathrm{L}$ of $0.01 \%(w / v)$ resazurin (Inlab Confiança, São Paulo, Brazil); a change in color from blue to red was indicative of microbial growth and thus the MIC was recorded as the lowest extract concentration at which there was no color change [28]. For the fungi, the MIC was defined as the lowest concentration able to inhibit the visual growth in comparison with the 100\% growth control. Each antimicrobial assay was performed in duplicate and repeated three times. The antimicrobial activity of the extract was classified according to MIC values as follows: $50-500 \mu \mathrm{g} / \mathrm{mL}=$ strong activity; $600-1500 \mu \mathrm{g} / \mathrm{mL}=$ moderate activity; and $>1500 \mu \mathrm{g} / \mathrm{mL}=$ weak activity or inactive [29].

2.9. Statistical Analysis. The data were expressed as mean \pm SD and submitted to one-way ANOVA followed by Bonferroni's test, with significance level at $p<0.05$.

\section{Results and Discussion}

Health treatments using medicinal plants are the less expensive and more accessible to the population, mainly in developing countries. However, the indiscriminate use of plant preparations or products with doubtful constitution and without rigorous standardization may pose a risk due to the toxicity of some plant compounds to human organism. For this reason, studies that evaluated the side effects and toxicity degree of preparations and compounds from medicinal plants are imperative. Within this context, this work evaluated the toxicity of an ethanolic extract from leaves of $M$. alba, a plant whose tissues have been extensively used with medicinal purposes, including as commercial formulations.

The phytochemical screening of the extract revealed the presence of coumarins, flavonoids, tannins, and triterpenes (Table 1). Toxicity of the extract was firstly evaluated using the microcrustacean $A$. salina, which is often used as a preliminary indicator of general toxicity of plant compounds; also, it is reported that toxicity to A. salina has a correlation with possible antitumor activity [30,31]. The results showed that the extract had no toxicity at all the tested concentrations, suggesting that it does not have a general toxicity.

In the oral toxicity assays, the groups of mice from control and extract treatments at both 300 and $2000 \mathrm{mg} / \mathrm{kg}$ b.w. did not show alterations in behavioral signals during the 14 days of experiments. However, the hematological analysis (Table 2) demonstrated significant $(p<0.05)$ reductions in $\mathrm{MCV}$ and $\mathrm{MCHC}$ in animals treated with the extract at $2000 \mathrm{mg} / \mathrm{kg}$, in comparison with control; MCHC was also lower than control in treatment at $300 \mathrm{mg} / \mathrm{kg}$. This result indicates that components of the $M$. alba extract may be acting on the erythrocytes causing a reduction of hemoglobin content and may be interfering with the hematopoiesis, causing the production of cells with lower volume. It has been reported that plant secondary metabolites may act directly on erythrocytes interfering with the integrity of plasma membrane and then causing shrinkage, reduction in hemoglobin content, and even destruction of the cells [32]. 
TABLE 2: Hematological parameters of animals from control group and treated with ethanolic extract of Morus alba leaves for 14 days.

\begin{tabular}{lccc}
\hline Parameter & Control & & Extract \\
& & $300 \mathrm{mg} / \mathrm{kg} \mathrm{b.w.}$ & $2000 \mathrm{mg} / \mathrm{kg} \mathrm{b.w.}$ \\
\hline Erythrocytes $\left(10^{6} / \mathrm{mm}^{3}\right)$ & $7.05 \pm 0.39$ & $7.84 \pm 0.58$ & $6.82 \pm 0.51$ \\
Hematocrit $(\%)$ & $39.95 \pm 0.21$ & $41.47 \pm 2.41$ & $36.50 \pm 4.95$ \\
Hemoglobin $(\mathrm{g} / \mathrm{dL})$ & $17.35 \pm 1.20$ & $15.62 \pm 1.05$ & $16.00 \pm 1.41$ \\
MCV (fL) & $64.00 \pm 5.00$ & $64.33 \pm 5.03^{\Delta}$ & $50.00 \pm 1.00^{* \Delta}$ \\
MCH (pg) & $26.97 \pm 1.91$ & $24.80 \pm 0.85$ & $21.20 \pm 4.53$ \\
MCHC (\%) & $38.20 \pm 1.01$ & $32.67 \pm 0.85^{*}$ & $32.20 \pm 2.01^{*}$ \\
Leukocytes $\left(10^{3} / \mathrm{mm}^{3}\right)$ & $8.26 \pm 0.43$ & $9.57 \pm 0.66^{\Delta}$ & $6.81 \pm 0.27^{* \Delta}$ \\
Segmented $(\%)$ & $22.68 \pm 1.16$ & $43.90 \pm 3.41^{* \Delta}$ & $55.71 \pm 3.12^{* \Delta}$ \\
Lymphocytes $(\%)$ & $58.88 \pm 1.70$ & $42.39 \pm 2.57^{* \Delta}$ & $29.65 \pm 0.92^{* \Delta}$ \\
$\quad$ Monocytes $(\%)$ & $18.44 \pm 3.55$ & $13.71 \pm 1.35$ & $14.61 \pm 0.64$ \\
\hline
\end{tabular}

${ }^{*}$ Significantly different $(p<0.05)$ from control treatment. ${ }^{\Delta}$ Significantly different $(p<0.05)$ from the other dose of M. alba leaf extract. MCV: mean corpuscular volume; $\mathrm{MCH}$ : mean corpuscular hemoglobin; MCHC: mean corpuscular hemoglobin concentration.

TABLE 3: Biochemical parameters of blood of animals from control and treatments with the ethanolic extract from Morus alba leaves for 14 days.

\begin{tabular}{|c|c|c|c|}
\hline \multirow{2}{*}{ Parameters } & \multirow{2}{*}{ Control } & \multicolumn{2}{|c|}{ Extract } \\
\hline & & $300 \mathrm{mg} / \mathrm{kg}$ b.w. & $2000 \mathrm{mg} / \mathrm{kg}$ b.w. \\
\hline Albumin (g/dL) & $2.14 \pm 0.17$ & $1.92 \pm 0.13$ & $2.25 \pm 0.25$ \\
\hline $\operatorname{ALT}(\mathrm{U} / \mathrm{L})$ & $78.50 \pm 2.12$ & $80.3 \pm 8.02^{\Delta}$ & $66.33 \pm 4.73^{* \Delta}$ \\
\hline AST (U/L) & $147.50 \pm 4.95$ & $149.67 \pm 6.81$ & $149.33 \pm 5.03$ \\
\hline Total protein (g/dL) & $6.16 \pm 0.23$ & $6.09 \pm 0.35$ & $6.13 \pm 0.17$ \\
\hline Alkaline phosphatase (IU/L) & $14.00 \pm 1.0$ & $12.33 \pm 2.52^{\Delta}$ & $37.00 \pm 2.65^{* \Delta}$ \\
\hline GGT (U/L) & $11.00 \pm 1.41$ & $12.67 \pm 1.15$ & $14.00 \pm 1.50$ \\
\hline Urea $(\mathrm{mg} / \mathrm{dL})$ & $54.33 \pm 4.93$ & $50.33 \pm 1.53$ & $53.33 \pm 2.08$ \\
\hline Creatinine $(\mathrm{mg} / \mathrm{dL})$ & $0.28 \pm 0.02$ & $0.28 \pm 0.02$ & $0.30 \pm 0.04$ \\
\hline
\end{tabular}

${ }^{*}$ Significantly different $(p<0.05)$ from control treatment. ${ }^{\Delta}$ Significantly different $(p<0.05)$ from the other dose of $M$. alba leaf extract.

Table 2 also shows that the number of leukocytes in animals treated with the extract at $2000 \mathrm{mg} / \mathrm{kg}$ was significantly lower $(p<0.05)$ than in control animals, having observed a reduction in the proportion of lymphocytes but an increase of segmented leukocytes. At the dose of $300 \mathrm{mg} / \mathrm{kg}$, the extract of $M$. alba also decreased the proportion of lymphocytes and increased the percentage of segmented leukocytes, although the number of total leukocytes was not altered. A possible explanation is that compounds of the extract resulted in a drastic decrease of blood lymphocytes, which stimulated the production of new leukocytes, leading to the increase in proportion of segmented cells. In summary, these results constitute an indication that this extract has an important effect on the immune cells.

Biochemical analysis (Table 3) revealed significant $(p<$ 0.05 ) alterations in the serum levels of the enzymes ALT and alkaline phosphatase in animals that received the extract at $2000 \mathrm{mg} / \mathrm{kg}$, in comparison with control. The group treated with the dose $300 \mathrm{mg} / \mathrm{kg}$ did not show significant $(p>0.05)$ variations. Since damage of liver cells usually results in a release of several types of enzymes, we can infer that the $M$. alba extract did not cause strong impairment of hepatocytes membrane. Indeed, no alterations or a decrease only of ALT levels, which is a more specific marker for damage to liver
TABLE 4: Evaluation of food and water consumption and weight gain of animals from control and treated with the ethanolic extract from leaves of Morus alba.

\begin{tabular}{lccc}
\hline \multirow{2}{*}{ Parameter } & Control & \multicolumn{2}{c}{ Extract } \\
& & $300 \mathrm{mg} / \mathrm{kg}$ b.w. & $2000 \mathrm{mg} / \mathrm{kg} \mathrm{b.w.}$ \\
\hline $\begin{array}{l}\text { Water consumed } \\
(\mathrm{mL})\end{array}$ & $35.00 \pm 1.05$ & $34.82 \pm 1.68$ & $34.29 \pm 1.27$ \\
$\begin{array}{l}\text { Food consumed } \\
(\mathrm{g})\end{array}$ & $28.68 \pm 1.23$ & $28.13 \pm 1.00$ & $27.09 \pm 1.28$ \\
Weight gain $(\mathrm{g})$ & $12.04 \pm 0.79$ & $11.98 \pm 0.49$ & $12.00 \pm 0.38$ \\
\hline
\end{tabular}

cells, has been interpreted as a signal of stability of the membranes of these cells [33]. An increase only in alkaline phosphatase level is usually indicative of obstruction of bile flow [4] and it is possible that the $M$. alba extract is acting at this level and not by disturbing the membrane of hepatocytes. The levels of GGT, which is a more specific marker for hepatic damage [34], were similar in all groups, corroborating that the $M$. alba extract did not exert hepatotoxic effect.

No differences in food and water consumption were detected between the groups as well as regarding the biomass gain (Table 4). The results from oral toxicity evaluation 

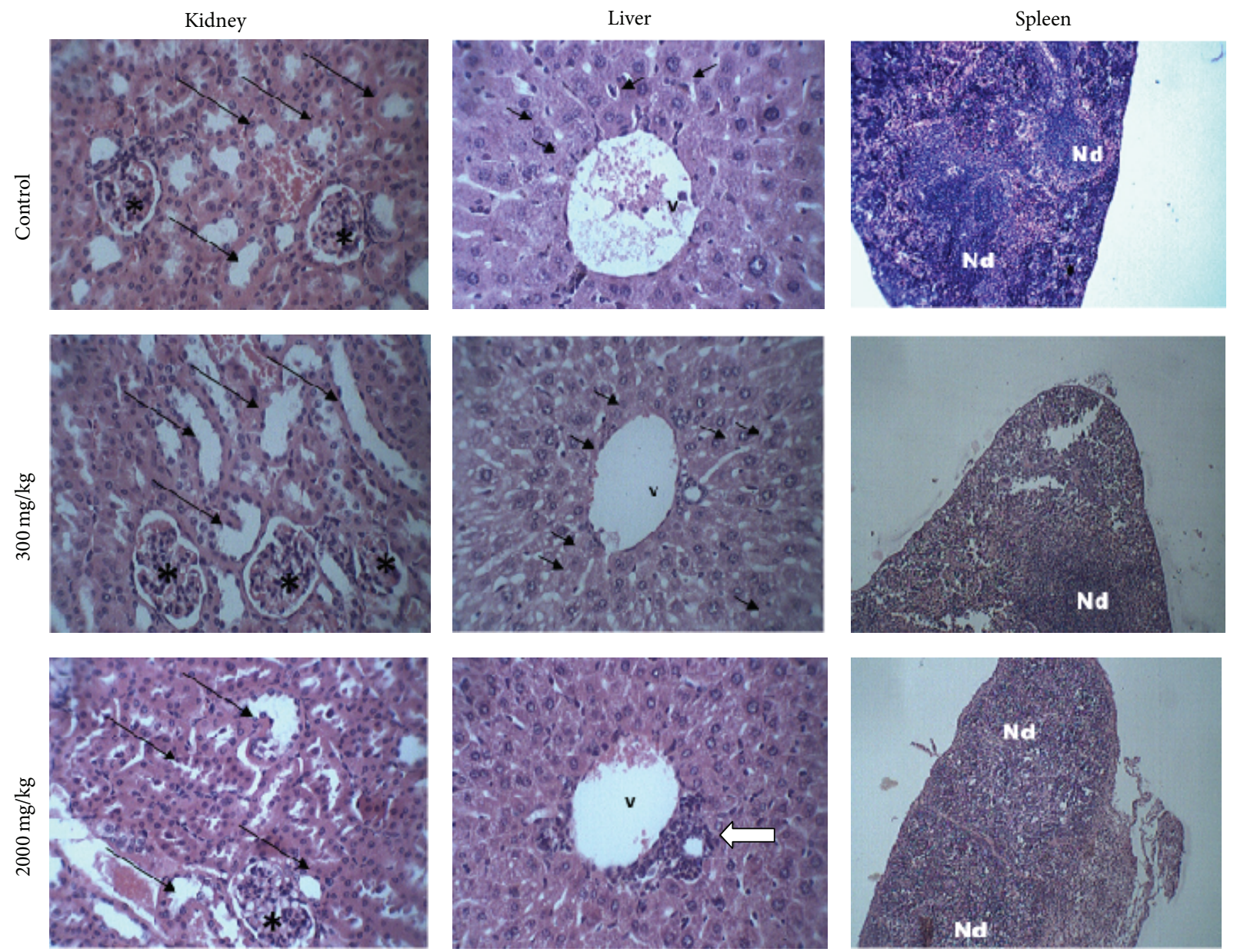

FIGURE 1: Histopathological analysis of kidneys, livers, and spleens of mice from control and treatments with the ethanolic extract from Morus alba leaves at 300 and $2000 \mathrm{mg} / \mathrm{kg}$ b.w. Kidneys: in control and treatment with $300 \mathrm{mg} / \mathrm{kg}$, the cortical region with the renal glomeruli ( $*$ ) and contorted tubules (arrows) without alterations can be seen. In treatment with $2000 \mathrm{mg} / \mathrm{kg}$, a reduction of the subcapsular space and turgid contorted tubules (arrows) is observed. Livers: photomicrography from control treatment shows the centrilobular vein (v) and a preserved organization of the hepatocytes bundles. In the image from treatment with $300 \mathrm{mg} / \mathrm{kg}$, reversible-type cytoplasm vacuolizations (arrows) can be seen while the photomicrograph of an animal that received $2000 \mathrm{mg} / \mathrm{kg}$ of extract shows a lymphocyte infiltration around the centrilobular vein (white arrow). Spleens: in control, the well-delimited lymphatic nodes (Nd) can be noticed, while, in images for treatments with 300 and $2000 \mathrm{mg} / \mathrm{kg}$, there is an expansion of lymphatic node (Nd) in the white pulp. All sections were stained with hematoxylin/eosin. Kidney and liver images: 400x. Spleen images: 100x.

indicated that the ethanolic extract from leaves of M. alba has low toxicity, since no death was observed even in assays at $2000 \mathrm{mg} / \mathrm{kg}$ dose [26]. However, the alterations found in hematological and biochemical analyses stimulated us to perform a histopathological study of the livers, kidneys, and spleens of the animals, since damage to these organs may be linked to the changes detected [35].

Photomicrographs obtained in the histopathological analysis are showed in Figure 1. The structure of the organs was preserved in control animals while a slight presence of reversible-type vacuolization was observed in hepatocytes of animals treated with the extract at $300 \mathrm{mg} / \mathrm{kg}$. On the other hand, all the organs from animals that received the extract at $2000 \mathrm{mg} / \mathrm{kg}$ showed alterations. The kidneys showed a decreasing of the subcapsular space and turgidity of the contorted tubules. In the livers, the presence of leukocyte infiltration around the centrilobular vein was detected, which can be associated with intracellular lesions. A high dispersion of the spleen white pulp was also observed, which is a region of lymphatic tissue containing B and T lymphocytes; this can explain the reduction in the number of lymphocytes recorded in hematological analysis.

The ethanolic extract of $M$. alba leaves can be considered more toxic than an ethanolic extract from Ocimum sanctum leaves, which did not promote mortality at 200,600, and $2000 \mathrm{mg} / \mathrm{kg}$ in 14 days and did not affect water consumption, body weight, and hematological and biochemical parameters. In addition, there were no alterations in the structure of liver, kidney, and spleen of mice treated with the $O$. sanctum extract at a dose of $800 \mathrm{mg} / \mathrm{kg}$ [36]. On the other hand, a leaf extract from Lawsonia inermis showed higher toxicity than the $M$. alba extract since it promoted pathological changes in liver 
TABLE 5: Minimal inhibitory concentrations (MIC) of ethanolic extract from Morus alba leaves against bacteria and fungi.

\begin{tabular}{lc}
\hline Microbial strain & MIC $(\mu \mathrm{g} / \mathrm{mL})$ \\
\hline Staphylococcus aureus ATCC-13150 & 512 \\
Staphylococcus aureus M-177 & 1,024 \\
Pseudomonas aeruginosa ATCC-9027 & 1,024 \\
Pseudomonas aeruginosa ATCC-P-03 & 1,024 \\
Candida albicans ATCC-76645 & 1,024 \\
Candida albicans LM-106 & 256 \\
Candida tropicalis ATCC-13083 & 512 \\
Candida tropicalis LM-6 & 1,024 \\
Candida krusei LM-656 & 512 \\
Candida krusei LM-978 & 512 \\
Aspergillus flavus KM-714 & 512 \\
Aspergillus niger LM-108 & $\mathrm{NI}$ \\
\hline
\end{tabular}

NI: no inhibition.

and kidney of rats at a dose of $1000 \mathrm{mg} / \mathrm{kg}$, with signals of degenerative/apoptotic changes [37].

Coumarins are known for their hepatotoxicity and have been reported to be toxic to mice and rats, including being able to increase the incidence of adenomas and carcinomas in lungs of rats $[38,39]$. Thus, this class of compounds may be involved in the alterations promoted by $M$. alba extract in oral toxicity assays. On the other hand, flavonoids are known to exert hepatoprotective and antioxidant effects [40] and thus may counterbalance the effects of potentially toxic compounds in the extract.

Among the several applications described for Morus plants, there is the use for combating infections caused by bacteria and fungi. The increase in the number of microbial strains resistant to the mostly used antibiotics has stimulated the search for new antimicrobial agents, especially those with natural origin [41]. In this way, we evaluated the antimicrobial activity of the ethanolic extract from $M$. alba leaves against bacteria and fungi with medical relevance. The results are summarized in Table 5 and show that the extract presented a strong activity (MIC of $256 \mu \mathrm{g} / \mathrm{mL}$ ) against C. albicans LM106 and moderate antimicrobial activity on the other strains, except $A$. niger, which was not sensitive to the extract. The bacterium most sensitive to the extract was $S$. aureus ATCC13150. The strains C. albicans ATCC-76645, C. albicans LM106, and C. krusei LM-656 were resistant to the positive controls used.

\section{Conclusions}

Ethanolic extract of $M$. alba leaves showed low oral toxicity to mice since no animal death was detected at a dose of $2000 \mathrm{mg} / \mathrm{kg}$. However, the extract promoted biochemical, hematological, and histopathological alterations at this dose, which indicates that caution is required regarding its use. At $300 \mathrm{mg} / \mathrm{kg}$, the extract did not show toxicity or cause irreversible cellular damages but altered the proportion of leukocyte types. The extract showed mainly moderate activity against the microbial pathogens evaluated.

\section{Conflict of Interests}

The authors declare that there is no conflict of interests regarding the publication of this paper.

\section{Acknowledgments}

The authors express their gratitude to the Fundação de Amparo à Ciência e Tecnologia do Estado de Pernambuco (FACEPE; APQ-0108-2.08/14), the Conselho Nacional de Desenvolvimento Científico e Tecnológico (CNPq; 472546/20120; 446902/2014-4) and the Coordenação de Aperfeiçoamento de Pessoal de Nível Superior (CAPES) for financial support. Patrícia Maria Guedes Paiva thanks CNPq for investigator research grant. Alisson Macário de Oliveira thanks CAPES for graduate scholarship.

\section{References}

[1] World Health Organization, WHO Traditional Medicine Strategy: 2014-2023, World Health Organization, Geneva, Switzerland, 2013.

[2] K. O. Soetan and O. O. Aiyelaagbe, "The need for bioactivitysafety evaluation and conservation of medicinal plants-a review," Journal of Medicinal Plants Research, vol. 3, no. 5, pp. 324-328, 2009.

[3] D. G. I. Teles and M. M. Costa, "Estudo da ação antimicrobiana conjunta de extratos aquosos de Tansagem (Plantago major L., Plantaginaceae) e Romã (Punica granatum L., Punicaceae) e interferência dos mesmos na ação da amoxicilina in vitro," Revista Brasileira de Plantas Medicinais, vol. 16, no. 2, pp. 323328, 2014.

[4] A. O. T. Ashafa and M. I. Kazeem, “Toxicopathological evaluation of hydroethanol extract of Dianthus basuticus in Wistar rats," Evidence-Based Complementary and Alternative Medicine. In press.

[5] J. Zhishen, T. Mengcheng, and W. Jianming, "The determination of flavonoid contents in mulberry and their scavenging effects on superoxide radicals," Food Chemistry, vol. 64, no. 4, pp. 555559, 1999.

[6] P. Dugo, P. Donato, F. Cacciola, M. P. Germanò, A. Rapisarda, and L. Mondello, "Characterization of the polyphenolic fraction of Morus alba leaves extracts by HPLC coupled to a hybrid ITTOF MS system," Journal of Separation Science, vol. 32, no. 21, pp. 3627-3634, 2009.

[7] S.-J. Piao, L.-X. Chen, N. Kang, and F. Qiu, "Simultaneous determination of five characteristic stilbene glycosides in root bark of Morus albus L. (Cortex Mori) using high-performance liquid chromatography," Phytochemical Analysis, vol. 22, no. 3, pp. 230-235, 2011.

[8] S. H. Kim, N. J. Kim, J. S. Choi, and J. C. Park, "Determination of flavonoid by HPLC and biological activities from the leaves of Cudrania tricuspidata Bureau," Journal of the Korean Society of Food Science and Nutrition, vol. 22, pp. 68-72, 1993.

[9] T. Fukai, K. Kaitou, and S. Terada, "Antimicrobial activity of 2-arylbenzofurans from Morus species against methicillinresistant Staphylococcus aureus," Fitoterapia, vol. 76, no. 7-8, pp. 708-711, 2005.

[10] S.-J. Dai, Z.-B. Ma, Y. Wu, R.-Y. Chen, and D.-Q. Yu, "Guangsangons F-J, anti-oxidant and anti-inflammatory Diels-Alder type adducts, from Morus macroura Miq.," Phytochemistry, vol. 65, no. 23, pp. 3135-3141, 2004. 
[11] J.-H. Liang, Y.-W. Fu, Q.-Z. Zhang, D.-H. Xu, B. Wang, and D.-J. Lin, "Identification and effect of two flavonoids from root bark of Morus alba against Ichthyophthirius multifiliis in grass carp," Journal of Agricultural and Food Chemistry, vol. 63, no. 5, pp. 1452-1459, 2015.

[12] A. Sheikhlar, A. R. Alimon, H. Daud et al., "White mulberry (Morus alba) foliage methanolic extract can alleviate Aeromonas hydrophila infection in African Catfish (Clarias gariepinus)," The Scientific World Journal, vol. 2014, Article ID 592709, 8 pages, 2014.

[13] J. Qin, M. Fan, J. He et al., "New cytotoxic and anti-inflammatory compounds isolated from Morus alba L.," Natural Product Research, 2015.

[14] M. Yimam, Y. C. Lee, T. W. Kim et al., "UP3005, a botanical composition containing two standardized extracts of Uncaria gambir and Morus alba, improves pain sensitivity and cartilage degradations in monosodium iodoacetate-induced rat $\mathrm{OA}$ disease model," Evidence-Based Complementary and Alternative Medicine, vol. 2015, Article ID 785638, 10 pages, 2015.

[15] H. G. Kim, H. U. Jeong, G. Park, H. Kim, Y. Lim, and M. S. Oh, "Mori Folium and Mori Fructus mixture attenuates highfat diet-induced cognitive deficits in mice," Evidence-Based Complementary and Alternative Medicine, vol. 2015, Article ID 379418, 8 pages, 2015.

[16] B. Andallu and N. C. Varadacharyulu, "Antioxidant role of mulberry (Morus indica L. cv. Anantha) leaves in streptozotocindiabetic rats," Clinica Chimica Acta, vol. 338, no. 1-2, pp. 3-10, 2003.

[17] S.-H. Fang, Y.-C. Hou, and P.-D. L. Chao, "Pharmacokinetic and pharmacodynamic interactions of morin and cyclosporin," Toxicology and Applied Pharmacology, vol. 205, no. 1, pp. 65-70, 2005.

[18] W. Wang, Y. Zu, Y. Fu, and T. Efferth, "In vitro antioxidant and antimicrobial activity of extracts from Morus alba L. leaves, stems and fruits," The American Journal of Chinese Medicine, vol. 40, no. 2, pp. 349-356, 2012.

[19] J.-H. Lee, S. Y. Bae, M. Oh, K. H. Kim, and M. S. Chung, "Antiviral effects of mulberry (Morus alba) juice and its fractions on foodborne viral surrogates," Foodborne Pathogens and Disease, vol. 11, no. 3, pp. 224-229, 2014.

[20] K. H. Seo, D. Y. Lee, R. H. Jeong et al., "Neuroprotective effect of prenylated arylbenzofuran and flavonoids from Morus alba fruits on glutamateinduced oxidative injury in HT22 hippocampal cells," Journal of Medicinal Food, vol. 18, no. 4, pp. 403-408, 2015.

[21] K. R. Markhan, Techniques of Flavonoids Identification, Academic Press, London, UK, 1982.

[22] H. Wagner and S. Bladt, Plant Drug Analysis: A Thin Layer Chromatography Atlas, Springer, New York, NY, USA, 2nd edition, 2001.

[23] M. Abreu, Triagem fitoquímica de plantas por cromatografia em camada delgada (CCD), Universidade de Ouro Preto, Ouro Preto, Brazil, 2000.

[24] B. N. Meyer, N. R. Ferrigni, J. E. Putnam, L. B. Jacobson, D. E. Nichols, and J. L. McLaughlin, "Brine shrimp: a convenient general bioassay for active plant constituents," Planta Medica, vol. 45, no. 1, pp. 31-34, 1982.

[25] E. R. Almeida, Estudo da atividade antinociceptiva central do extrato hidroalcoólico das sementes de Dioclea grandiflora Mart ex. Benth (Fabaceae) e dois de seus constituintes quimícos: Dioclenol e Dioflorina [Ph.D. thesis], Universidade Federal da Paraíba, Paraíba, Brazil, 2002.
[26] Organization for Economic Cooperation and Development, OECD Guideline for Testing of Chemicals. Guideline 423: Acute Oral Toxicity-Acute Toxic Class Method, Organization for Economic Cooperation and Development, Paris, France, 2001.

[27] J. Kiernan, Histological and Histochemical Methods: Theory and Practice, Cold Spring Harbor Laboratory Press, Long Island, NY, USA, 4th edition, 2008.

[28] C. M. Mann and J. L. Markham, "A new method for determining the minimum inhibitory concentration of essential oils," Journal of Applied Microbiology, vol. 84, no. 4, pp. 538-544, 1998.

[29] A. Sartoratto, A. L. M. Machado, C. Delarmelina, G. M. Figueira, M. C. T. Duarte, and V. L. G. Rehder, "Composition and antimicrobial activity of essential oils from aromatic plants used in Brazil," Brazilian Journal of Microbiology, vol. 35, no. 4, pp. 275-280, 2004.

[30] J. R. Naidu, R. Ismail, and S. Sasidharan, "Acute oral toxicity and brine shrimp lethality of methanol extract of Mentha Spicata L. (Lamiaceae)," Tropical Journal of Pharmaceutical Research, vol. 13, no. 1, pp. 101-107, 2014.

[31] A. S. Leite, A. F. Dantas, G. L. S. Oliveira et al., "Evaluation of toxic, cytotoxic, mutagenic, and antimutagenic activities of natural and technical cashew nut shell liquids using the Allium cepa and Artemia salina bioassays," BioMed Research International, vol. 2015, Article ID 626835, 16 pages, 2015.

[32] P. Nwankpa, E. N. Agomuo, G. C. Uloneme, J. N. Egwurugwu, Y. N. Omeh, and G. C. Nwakwuo, "Effect of Phyllanthus amarus leaf extract on alterations of haematological parameters in Salmonellae typhi infested wistar albino rats," Scientific Research and Essays, vol. 9, no. 1, pp. 7-12, 2014.

[33] R. C. Ekeanyanwu and O. U. Njoku, "Acute and subacute oral toxicity study on the flavonoid rich fraction of Monodora tenuifolia seed in albino rats," Asian Pacific Journal of Tropical Biomedicine, vol. 4, no. 3, pp. 194-202, 2014.

[34] V. T. Motta, Bioquímica clínica para o laboratório: princípios e interpretações, MedBook, 5th edition, 2009.

[35] V. Kuete, Toxicological Survey of African Medicinal Plants, Elsevier, 1st edition, 2014.

[36] M. K. Gautam and R. K. Goel, “Toxicological study of Ocimum sanctum Linn leaves: hematological, biochemical, and histopathological studies," Journal of Toxicology, vol. 2014, Article ID 135654, 9 pages, 2014.

[37] M. A. Z. Alferah, "Toxicity induced histological changes in selected organs of male (Wistar) rats by Lawsonia inermis leaf extract," European Journal of Medicinal Plants, vol. 2, no. 2, pp. 151-158, 2012.

[38] S. L. Born, A. M. Api, R. A. Ford, F. R. Lefever, and D. R. Hawkins, "Comparative metabolism and kinetics of coumarin in mice and rats," Food and Chemical Toxicology, vol. 41, no. 2, pp. 247-258, 2003.

[39] P. A. Akah, C. C. Osigwe, and C. S. Nworu, "Reversal of coumarin-induced toxicity by the extracts and fractions of Ageratum conyzoides," Asian Journal of Medical Sciences, vol. 2, no. 3, pp. 121-126, 2010.

[40] R. Jayaraj, U. Deb, A. S. B. Bhaskar, G. B. K. S. Prasad, and P. V. L. Rao, "Hepatoprotective efficacy of certain flavonoids against microcystin induced toxicity in mice," Environmental Toxicology, vol. 22, no. 5, pp. 472-479, 2007.

[41] Y. Miyasaki, J. D. Rabenstein, J. Rhea et al., "Isolation and characterization of antimicrobial compounds in plant extracts against multidrug-resistant Acinetobacter baumannii," PLoS ONE, vol. 8, no. 4, Article ID e61594, 2013. 


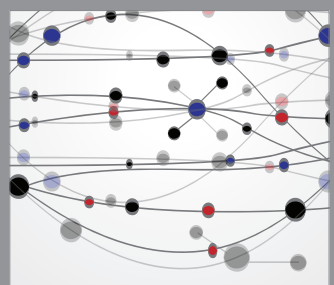

The Scientific World Journal
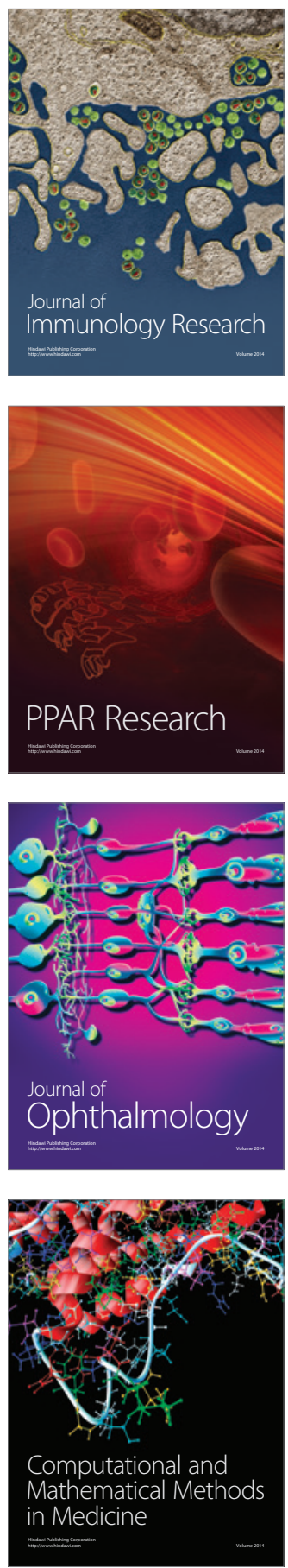

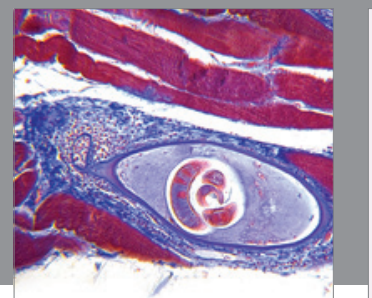

Gastroenterology

Research and Practice
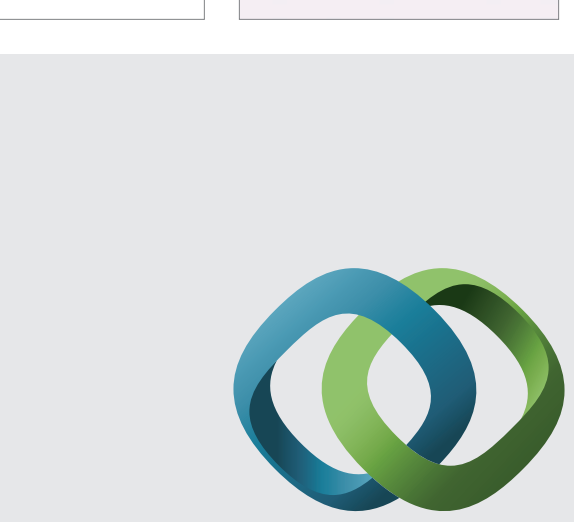

\section{Hindawi}

Submit your manuscripts at

http://www.hindawi.com
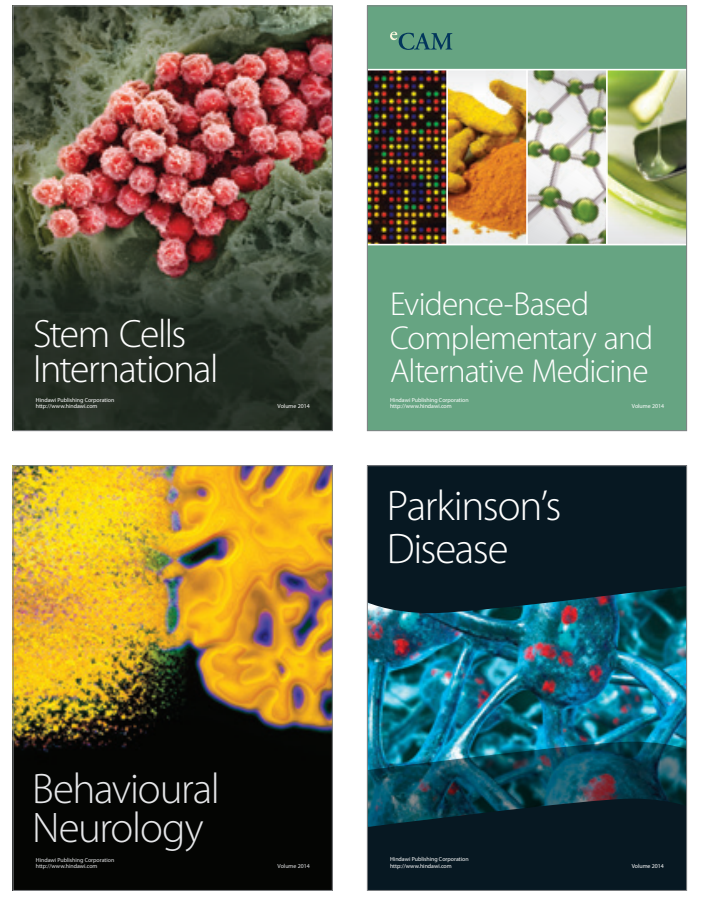
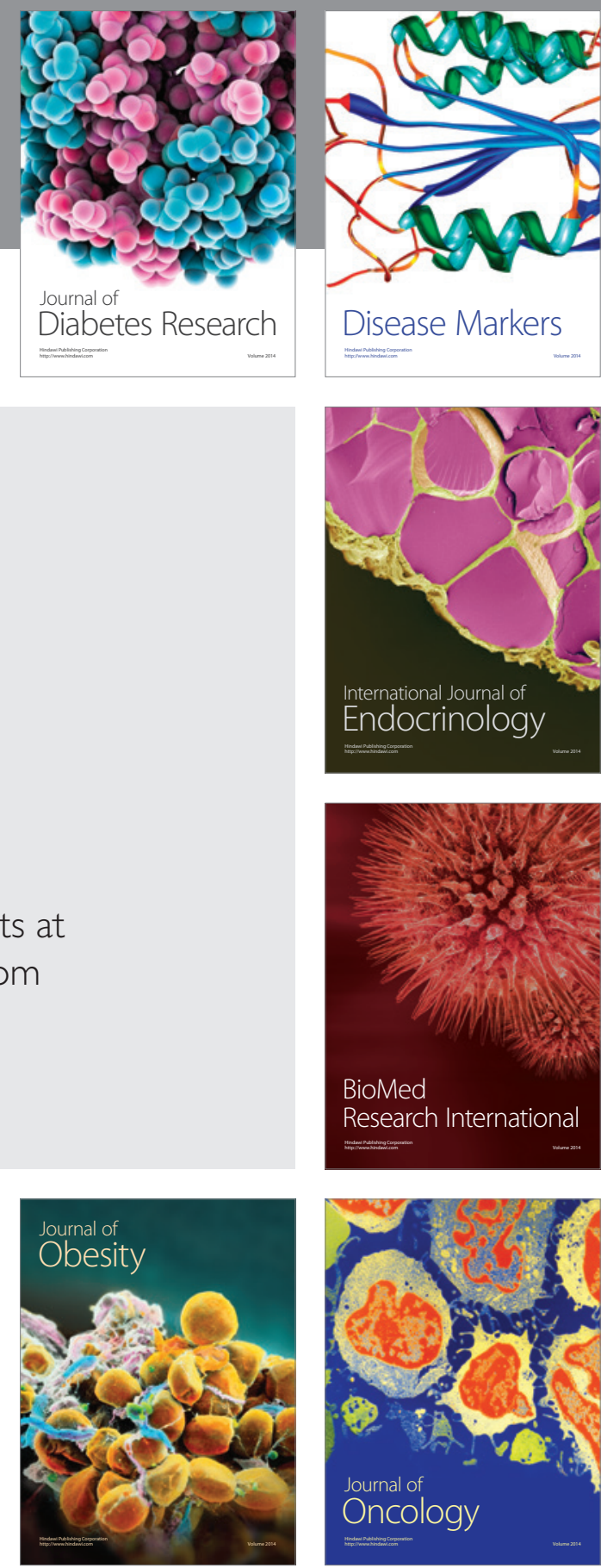

Disease Markers
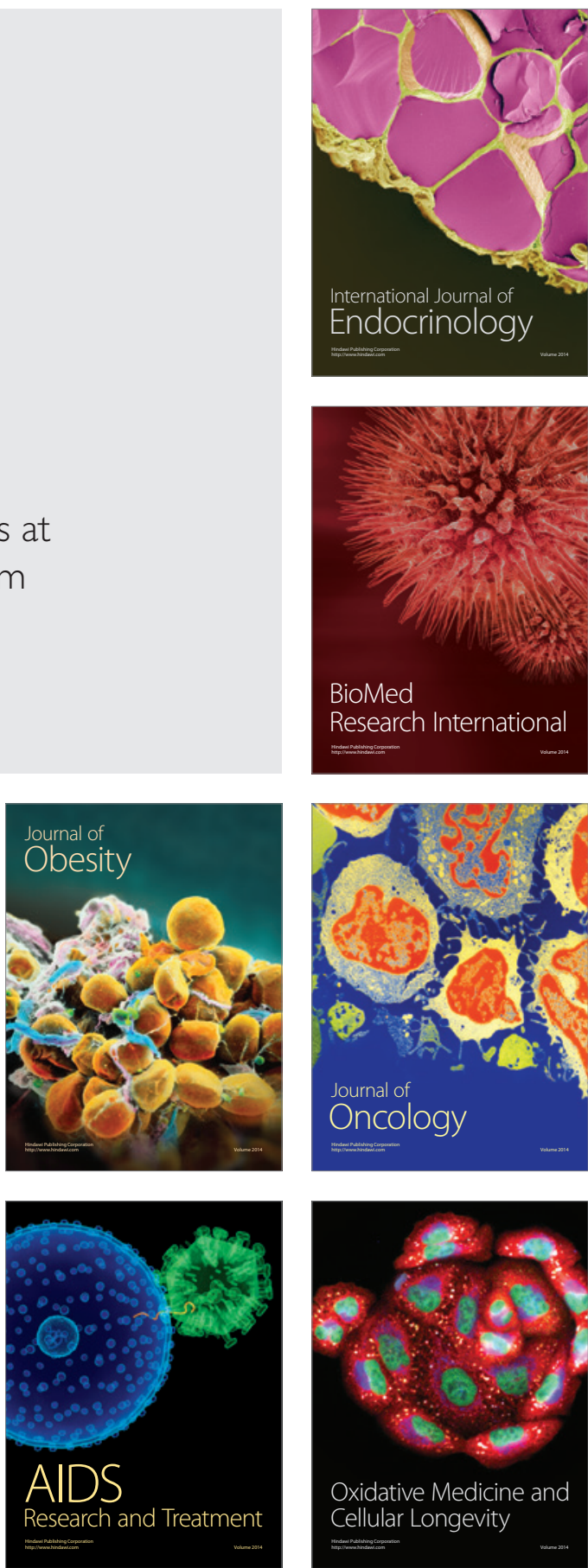